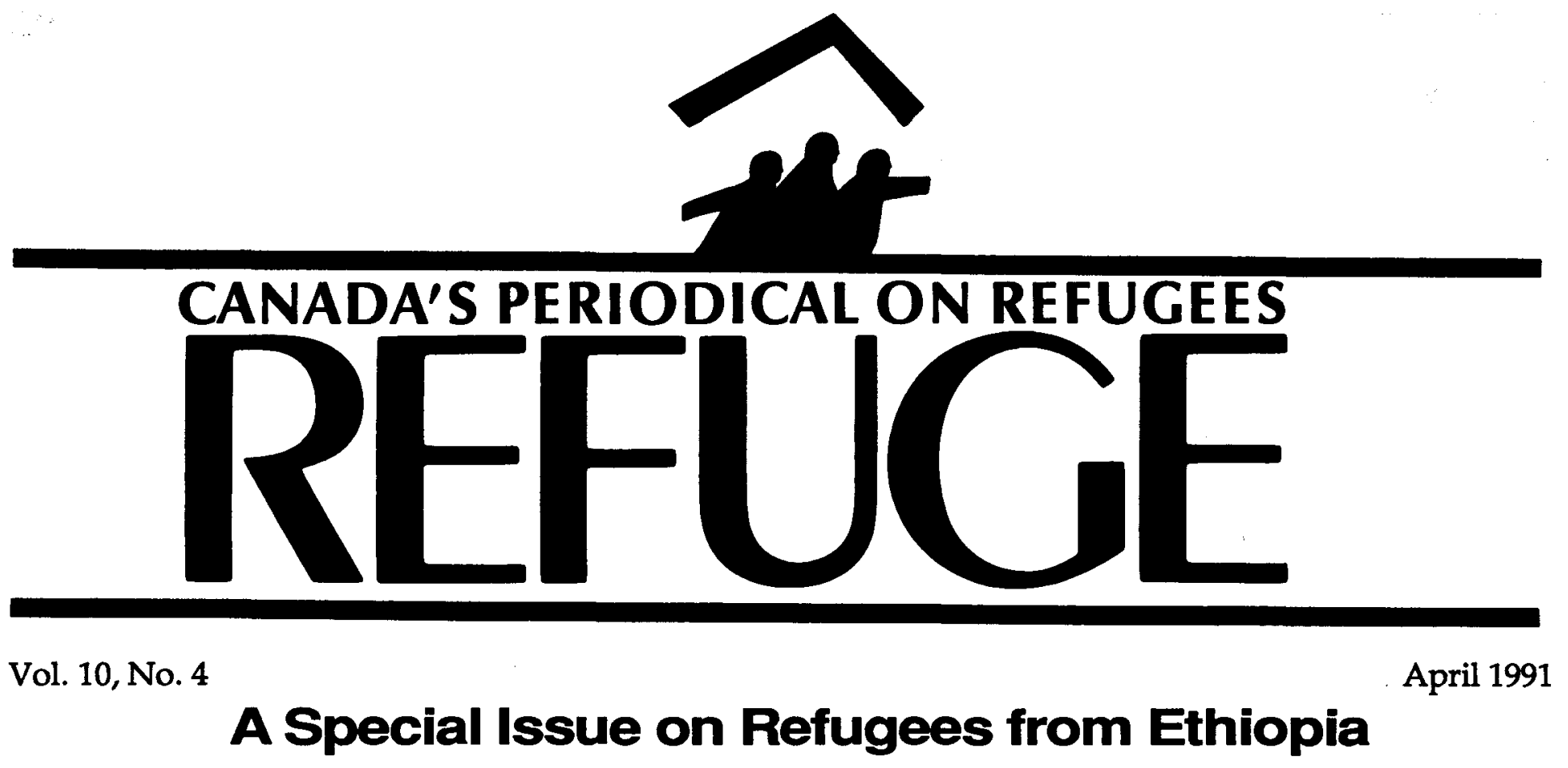

\title{
In Memorlam
}

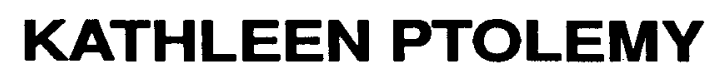

I had the good fortune of knowing Kathleen as a colleague, neighbour and friend.

All those here who worked with Kathleen would, I think, agree that she was an absolute pleasure to work with. She was collaborative, dependable, thorough, thoughtful, absolutely honest and direct without being insensitive to the feelings of others.

She was an example of how to bring out the best in people. She used to say she was a process person - as concerned for the way a decision was made as the actual decision itself. At meetings she would always come fully prepared, not only for the issue, but also to listen to others before speaking herself. When she spoke she was clear and her focus invariably helped to resolve matters. It was these skills that enabled Kathleen to do so much for so many people.

To give you a sense of just how great her contribution was, I thought I would tell you of a conversation I had yesterday with Beth Ferris, a friend and colleague of Kathleen from the World Council of Churches in Geneva. Beth related to me the overwhelming sadness that so many people in Geneva felt upon hearing of Kathleen's death. While Beth expected that those who worked in Africa would be particularly upset at Kathleen's passing, because of all the work Kathleen had done there, Beth did not expect the response shegot from other departments as well. One of her colleagues on the Middle East desk was most distraught, relating how Kathleen had done so much for Palestinians. Another colleague on the Latin American desk wept when remembering how Kathleen had been one of the first to respond to the desperate call for help by Chileans fleeing for their lives after the coup in their country.

As a neighbour, Kathleen epitomized all the old-fashioned values that are so hard to find today. Her door, both literally and figuratively, was always open. The Ptolemy kitchen should perhaps be protected as a historical site for so numerous have been the visitors and world travellers that have found comfort there. Kathleen, I know, would want it to be said that she herself drew enormous enjoyment and support from her neighbours. Her commitment to community was constantly fuelled by the kindness of those that lived near her.

As a friend, Kathleen was warm, generous, supportive and absolutely loyal. She was all too willing to put aside her own needs and agenda for someone close to her. Yet, as I think about her friendship, I realize that no matter what I say about Kathleen, a more powerful portrait can be drawn from the words of the lady herself.

Several weeks ago I asked her if, when looking over her life, she had any regrets. She said no, that although she could have done a few things better as a teenager, she had no regrets. She then quietly added that she knew she had never compromised herself.

In speaking about death, Kathleen said that she did not fear it. Her anguish and grief in dying was in being separated from Dave, Margie, Rob and others that she dearly loved. As for death itself, Kathleen felt it marked a new beginning. She believed that if you lived a decent life, at death you joined in communion with other decent souls who had died before you. Her philosophy was close to 
that of Teillard de Chardin. In describing his most "dearest and profound conviction" this French scientist, anthropologist, and "seer" to some wrote:

I believe what gives the universe ...its consistence is not the apparent solidity of the materials from which bodies are made. Rather it is the flame of organic development which has been running through the world since the beginning of time, consistently building itself up...Far from being impermanent and accidental, it is souls, and alliances of

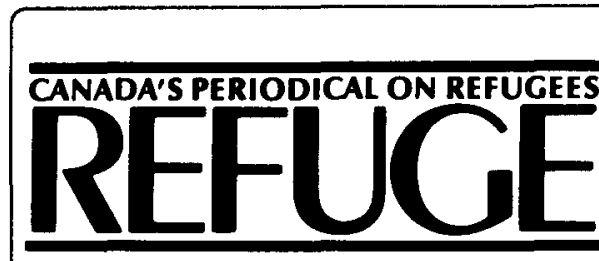

Centre for Refugee Studies, York University, Suite 234 Adminiatrative Studies Buildin E. 4700 Keele Street, North York, Ontario, Carreda M3J 1P3

Telephone: (416) 736-5663 Fax (416) 736-5837 Electronic Mail via Bitnet Addrese: REFUGE YORKVMI

Guest Editor: John Sorenson Editor: Howard Adelman Assistant Editor: Judy Hosein Circulation Manager: Helen Gross Assistant to the Circulation Manager: Ching Man (C.M.) Wong

Refuge is dedicated to the encouragement of assistance to refugees by providing a forum for sharing information and opinion on Canadian and international issues pertaining to refugees. It is published four times a year by the Centre for Refugee Studies. It is a non-profit, independant periodical supported by private donations and by subscriptions. It is a forum for discussion, and the views expressed do not necessarily reflect those of its funders or staff.

All material in Refuge may be reproduced without permission unless copyrighted or otherwise indicated. Credit should be given to the author or source, if named.

Subscription rates for one year are: Canada $\$ 25.00$

Overseas $\$ 30.00$ (U.S.)

Please enclose payment with your order.

Layout and Typesetting:

Alpha Desktop Publishing, (416) 897-5678

Logo Design:

Dreadnought Co-operative Inc, Toronto

Second Class Mall Regiatration No. 5512 ISSN 0229-5113 souls, it is energies of souls that alone progress infallibly, and it is they alone that will endure...

What radiates from living beings is more valuable than their caresses.

What radiated from Kathleen is, I believe, ultimately more valuable than her mortality. As I loved her, I shall miss her, more deeply than words can express. But I can celebrate her life. It will be a beacon for me, a constant reminder that one can live with integrity, and with compassion for others in the larger world in which we live.

Ninette Kelley

\section{ICCR MOURNS}

The Inter-Church Committee for Refugees mourns the untimely death at 51 of Kathleen Ptolemy, its first Coordinator. Kathleen most recently served as Anglican church consultant for Refugee Affairs. She was a former Secretary of the Canadian Council for Refugees. Kathleen championed the rights of the refugee. She was nurturer, encourager, prober, information source and personal helper for many refugee workers and refugees.

Emilio Castro, General Secretary of the World Council of Churches said in his letter of condolence, "We shall cherish ... her passionate solidarity with the "least among us", and her firm commitment to truth and justice ..."

The funeral took place in Toronto on Saturday, March 16, 1991.

Memorial donations to:

Quaker Committee for Refugees

c/o Nancy Pocock

52 Elgin Avenue

Toronto, Ontario M5R 2V8 or to:

The Primate's Fund

Anglican Church of Canada

600 Jarvis Street

Toronto, Ontario M4E 1N3

Condolences to:

David, Margie and Rob Ptolemy

28 Bracken Avenue

Toronto, Ontario M4E 1N3
Donations welcome.

Please direct your inquires to the Centre for Refugee Studies, York University.
IN THIS ISSUE...

3 Ethiopia's Refugees John Sorenson

6 Stranded 'Birds of Passage'?: Eritrean and Ethiopian Refugees in Khartoum Gaim Kibreab

12 Women Refugees: Empowerment \& Vulnerability ...... Helene Moussa

15 Resettled Refugees from Ethiopia: Who Gets Into the United States Peter Koehn

21 Cross Cultural Understandings of Independence and Dependence: Conflict in the Resettlement of Single Ethiopian Males Lucia Ann McSpadden 